\title{
Highlights Rangeland Ecology \& Management, March 2011
}

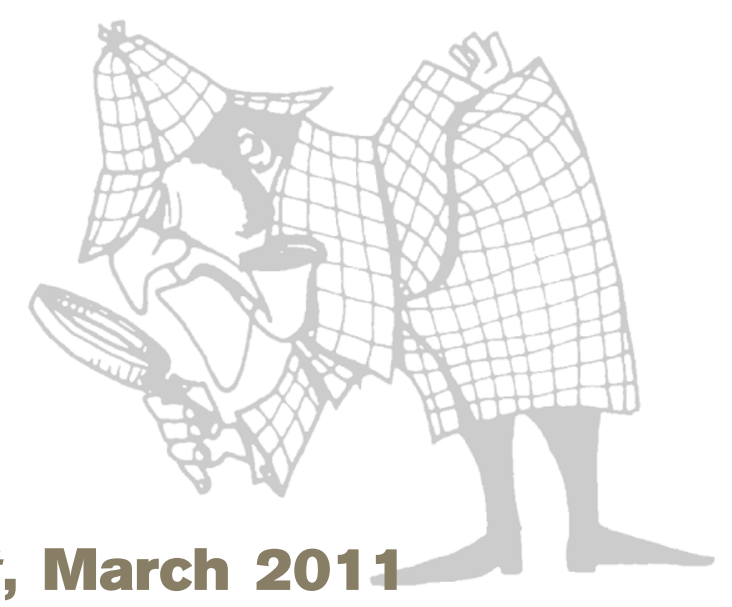

\section{Songbird Relationships to Shrub-Steppe Ecological Site Characteristics}

Mary I. Williams, Ginger B. Paige, Thomas L. Thurow, Ann L. Hild, and Kenneth G. Gerow

Ecological sites can be used to manage rangeland for multiple uses, but little is known of their links to wildlife habitat traits. We characterized shrub-steppe ecological sites to test whether songbird density and diversity differ among ecological sites and to identify quantifiable site characteristics that account for significant variation in songbirds. Vegetation structure represented as basal and canopy gaps, cover, height, and shrub density differentiated the ecological sites and were related to songbird density and diversity. By incorporating vegetation structure into ecological site descriptions, managers would be provided with tools needed to evaluate current songbird habitat and site conditions.

\section{Aspen Recovery Since Wolf Reintroduction on the Northern Yellowstone Winter Range}

David S. Kimble, Daniel B. Tyers, Jim Robison-Cox, and Bok F. Sowell

Reintroduction of wolves into Yellowstone National Park created interest in a possible rebound in quaking aspen regeneration due to a smaller population of elk: the primary prey for wolves and primary browser of aspen. A large aspen survey on the Northern Yellowstone Winter Range completed 4 years before wolf reintroduction was repeated 11 years after wolf reintroduction. Despite improved aspen conditions in select areas, overall aspen density has not increased on a large scale, and several factors, including browsing, continue to suppress aspen regeneration. It is important to examine multiple sites over a large area before making inferences about elk browsing intensity and aspen regeneration on the landscape scale.

\section{Wildlife Responses to Long-Term Application of Biosolids to Grasslands in North Carolina}

\section{Brian E. Washburn and Michael J. Begier}

Applications of biosolids to grassland areas might alter the attractiveness of those habitats to wildlife. We compared changes in plant communities and wildlife use of grasslands that received biosolids annually for more than 20 years to untreated (control) grassland areas on a military airfield. We observed some differences in wildlife use of biosolids and untreated (control) areas and these patterns were species-specific and often related to season. Long-term application of biosolids altered plant communities and influenced wildlife use of grassland areas and thus might be useful for accomplishing species-specific wildlife and habitat management objectives.

\section{Transition From Sagebrush Steppe to Annual Grass (Bromus tectorum): Influence on Belowground Carbon and Nitrogen}

Benjamin M. Rau, Dale W. Johnson, Robert R. Blank, Annmarrie Lucchesi, Todd G. Caldwell, and Eugene W. Schupp

The exotic annual cheatgrass (Bromus tectorum) has invaded millions of acres of rangelands within the intermountain west. We analyzed the influence of cheatgrass invasion on belowground organic carbon from seven sites across the intermountain west. We found that cheatgrass invasion alters the distribution of roots within the soil profile, which could lead to large reductions in belowground organic carbon storage. Given the large area affected by cheatgrass invasion and the potential for it to alter fire regimes, invaded rangelands could become a large source of $\mathrm{CO}_{2}$ emissions. 
Fire Effects on the Cheatgrass Seed Bank Pathogen Pyrenophora semeniperda

\section{Julie Beckstead, Laura E. Street, Susan E. Meyer,} and Phil S. Allen

How does fire impact the survival of a naturally occurring seed pathogen, Pyrenophora semeniperda, and seeds of its host, cheatgrass (Bromus tectorum)? Specifically, does burning facilitate host escape from the pathogen (i.e., window for cheatgrass expansion) or increase host vulnerability? Integrating our laboratory thermal death measurements with several field studies, it is clear that annual grassland fires in our study, whether prescribed burns or wildfires, were not hot enough to eliminate $P$. semeniperda from the seed zone. The ability of this pathogen to survive fire means that pathogen-caused mortality will continue unabated, whether or not a site burns.

\section{Using Participatory Workshops to Integrate State-and-Transition Models Created With Local Knowledge and Ecological Data}

\section{Corrine Noel Knapp, Maria Fernandez-Gimenez, Emily Kachergis, and Aleta Rudeen}

State-and-transition models (STMs) depict current understanding of vegetation dynamics and are being created for most ecological sites in the United States. We report on a series of participatory workshops where stakeholders helped to integrate STMs developed for the same region using local knowledge and ecological field data. We conclude that local knowledge and ecological data can complement one another, providing different types of information at different spatial and temporal scales. As STM development continues, it is critical that range professionals think systematically about what different forms of data might contribute to model development.

\section{Disturbance to Surface Lithic Components of Archaeological Sites by Drill Seeding}

Neal M. Bryan, Val Jo Anderson, and Rachel A. Fugal

Pending archaeological clearance for federally funded range improvement treatments in the United States can result in the postponement or exclusion of effective seeding practices. Delayed seeding can cause poor seed establishment, increased weeds, recurrent fire, accelerated soil erosion, and damage to cultural sites. We measured the displacement and damage that lithic artifacts would incur if missed in an inventory and subsequently subjected to drill seeding treatments. Minimal effects of drill seeding on lithics suggest the treatment could proceed with less-intensive archaeological surveys especially because drill seeding may carry less risk to cultural sites than no treatment at all.
Measuring Eastern Redcedar (Juniperus virginiana L.) Mass With the Use of Satellite Imagery

\author{
Patrick J. Starks, Brad C. Venuto, John A. Eckroat, \\ and Tom Lucas
}

Industrial-scale plans are being considered to use Eastern redcedar (Juniperus virginiana L.) as a biofuel source, but large-area inventories are needed to assess redcedar availability. We used remote sensing to develop and validate an allometric equation relating redcedar canopy area to mass. Canopy area was a good predictor of mass $\left(r^{2}=0.85\right)$, and predicted redcedar mass within 2-4 metric tons per hectare (0.9-1.8 US tons per acre) of the measured range on the validation site. The results indicate that $0.45-\mathrm{m}^{2}$ spatial resolution multispectral imagery can be a useful tool for rapid and reliable measurement of redcedar mass.

\section{Using Digital Photography to Examine Grazing in Montane Meadows}

\section{Susan K. Mcllroy, Barbara H. Allen-Diaz, and Alexander C. Berg}

Montane meadows serve a critical role in forests, and animal grazing is thought to disproportionately occur within these areas. This study documented real-time animal presence in montane meadows on the Sierra National Forest (California, USA), identified the effects of fencing on animal distribution, and tested digital photography as a tool for monitoring cattle. Fencing affected the distribution of both cattle and deer, but there was no statistically significant difference. We identified repeated cattle trespass within fences and documented highly concentrated cattle presence outside fences, highlighting the challenges of fencing meadows to restrict grazing.

\section{Influence of Grazing Management on Plant Diversity of Highland Sourveld Grassland, KwaZulu-Natal, South Africa}

Tim G. O'Connor, Greg Martindale, Craig D. Morris, Alan Short, Ed T. F. Witkowski, and Rob Scott-Shaw

Grazing management may be used toward successful biodiversity conservation in the grasslands of South Africa. Using long-term grazing trials, we demonstrated that plant diversity of non-grasses in species-rich grassland declines with increased stocking rates or with an increased proportion of sheep versus cattle. Although a few species that first colonize disturbed lands may increase under these circumstances, some species behave as "decreasers" and may face local extirpation. Both management variables can be easily modified in order to promote persistence of plant diversity. 


\section{Vegetation Production Responses to October Grazing in the Nebraska Sandhills}

Eric M. Mousel, Walter H. Schacht, Patrick E. Reece, Amy E. Herron, and Ann Koehler

Timing of summer grazing and fall stocking rate effects on vegetation are critical to extending the grazing season in the Nebraska Sandhills. We studied the vegetation response to timing of summer grazing and October stocking rate on two different sites. Site 1 was dominated by warm-season grasses, and site 2 was dominated by cool-season grasses. Vegetation production was not affected on warm-season dominated sites. Increasing October stocking rate on the site dominated by cool-season grasses, however, reduced production by $25 \%$. Heavy stocking in October over several years on sites dominated by cool-season grasses will reduce production of cool-season grasses.

\section{Spring Precipitation as a Predictor for Peak Standing Crop of Mixed-Grass Prairie}

\section{J. Wiles, Gale Dunn, Jeff Printz, Bob Patton, and Anne Nyren}

Ranchers and range managers need a decision support tool that provides a reasonably accurate prediction of forage growth potential early in the season to help users make stocking decisions. We evaluated spring monthly precipitation as a potential predictor of forage production compared to annual and growing-season precipitation. Results indicated that annual or growing-season precipitation were not good predictors of peak standing crop. The best predictor was total precipitation in April and May for Montana; May and June for North Dakota; and April, May, and June for Wyoming, when precipitation was less than the long-term average.

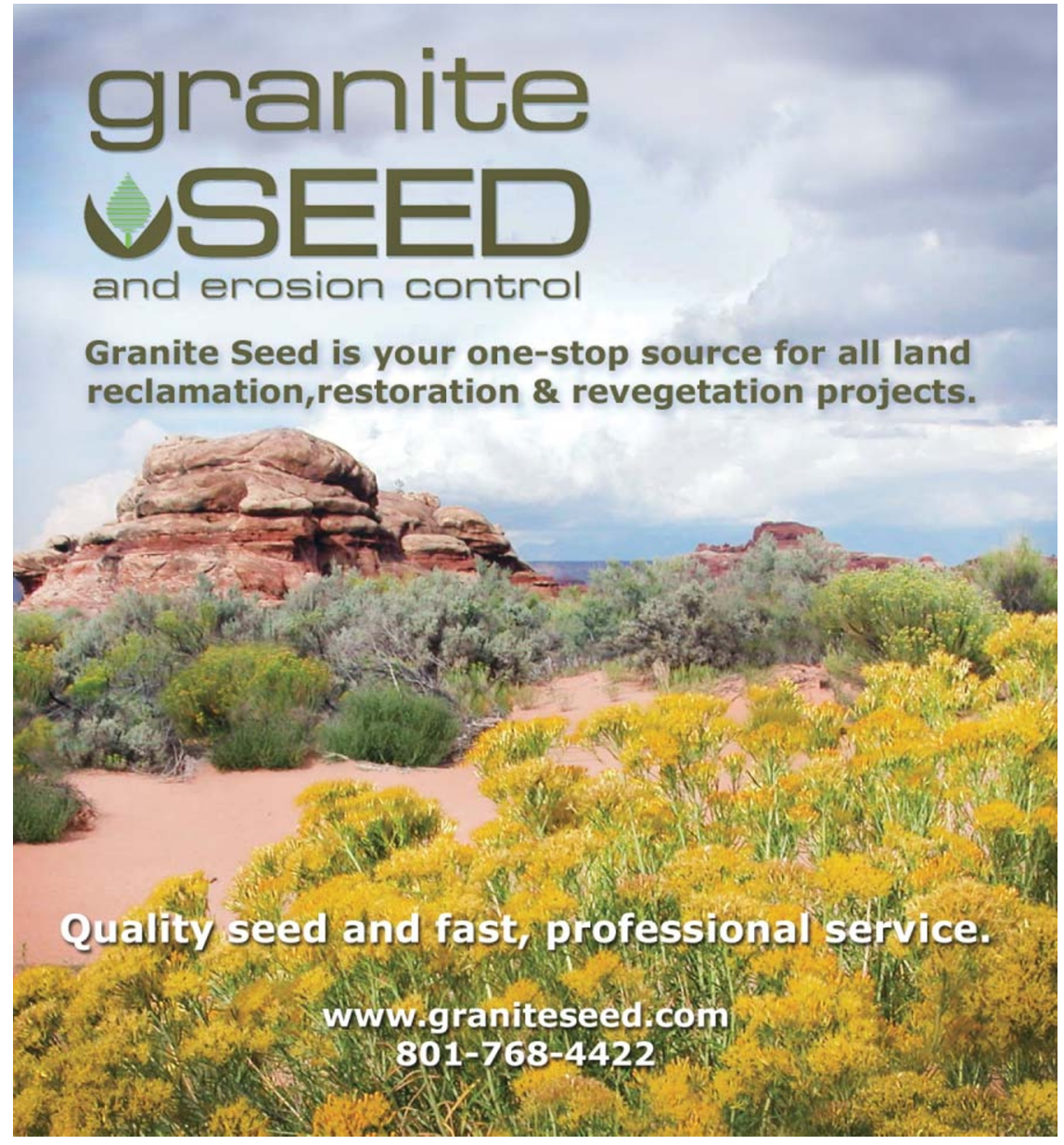

